\title{
ESTIMATING WATER AVAILABILITY USING THE SCS-CN METHOD BASED ON LONG TERM HYDROLOGIC SIMULATION AND THE GEOGRAPHIC INFORMATION SYSTEM
}

\author{
Atie Tri Juniati $^{1 *}$, Dwita Sutjiningsih ${ }^{2}$, Herr Soeryantono $^{2}$, Eko Kusratmoko $^{3}$ \\ ${ }^{1}$ Civil Engineering Study Program, Faculty of Engineering, Universitas Pancasila, Jakarta 16411, \\ Indonesia \\ ${ }^{2}$ Department of Civil Engineering, Faculty of Engineering, Universitas Indonesia, Kampus UI \\ Depok, Depok 16424, Indonesia \\ ${ }^{3}$ Department of Geography, Faculty of Mathematics and Natural Sciences, Universitas Indonesia, \\ Kampus UI Depok, Depok 16424, Indonesia
}

(Received: December 2018 / Revised: July 2019 / Accepted: October 2019)

\begin{abstract}
Water is one of the main resources for sustainable city development. To ensure the availability of adequate water for human use, water resource managers need to estimate the amounts of water that enter, pass through, and leave individual watersheds. This is a challenge, because the relative magnitudes of the transfers of individual components in the hydrologic cycle can vary greatly. This paper analyses water availability estimation using the modified Soil Conservation Service Curve Number (SCS-CN) model. The model provides a hydrologically sound procedure to better represent capture behaviour. The study focuses on upper catchments located in West Java, Indonesia. Water availability estimation from this catchment area is needed to understand changes in river flow, as it constitutes information for the Indonesian Regional Water Utility Company Tirta Pakuan) in meeting the clean water needs of Bogor city. The existing SCS-CN model determines the Curve Number $(\mathrm{CN})$ variable using Antecedent Moisture Condition (AMC). Daily moisture storage is updated based on varying the curve number and other hydrologic abstractions. A model was used to estimate stream flow components, direct-surface runoff, base flow, and hydrological abstractions. The calibration results indicate good model performance, with R2 and Nash Sutcliffe efficiency values for simulated monthly data of 0.62 and 0.36 respectively. The model was also successfully validated in the upper Cisadane catchment area by the respective R2 and Nash Sutcliffe efficiency values of 0.65 and 0.42 . Validation of the model indicates that it reasonably simulates the catchment response and is suitable for use as a tool in estimating water availability. From these estimates, and in accordance with the data used, it can be concluded that the level of water availability can still meet Bogor's water needs from 2004-2009.
\end{abstract}

Keywords: Long term hydrologic simulation; SCS-CN model; Upper Cisadane; Water availability; West Java

\section{INTRODUCTION}

Rapid urban growth puts pressure on the environment, and is the cause of social change, infrastructure development and pollution problems. Water sources are one of the main needs for sustainable city development.

\footnotetext{
*Corresponding author's email: atie.tri31@ui.ac.id, Tel.+62-816-1390449
}

Permalink/DOI: https://doi.org/10.14716/ijtech.v10i5.2716 
Water managers, particularly in less developed countries, face issues with regard to lack of hydrological data and limitations in terms of resources and equipment to collect such data. In cases where hydrological data is scarce or incomplete, long term hydrologic simulation can help augment what is available. The availability of rainfall data over long periods, for example, can be used to extend a smaller stream flow dataset through long term simulation, which is useful for water resource planning and watershed management. Long-term hydrologic data are specifically required for analyses of water availability; computation of daily, fortnightly and monthly flows for reservoir operation; and drought analyses. (Mishra and Singh 2003).

Long term hydrologic simulation is conducted in various ways. Attempts at cataloguing such models have been previously made: the inventory prepared by the US Bureau of Reclamation in 1991 listed 64 watershed models in four categories; Wurbs (1998) categorized them into seven groups; at least two compilations of related proceedings exist, the first by Burton (1993) and the second by the Subcommittee on Hydrology of the IACWD (1998), which documented models developed by US federal agencies; and finally Singh (1995) discussed 26 models in use around the world. The models vary in their description of the hydrological cycle components, input complexities, number of parameters, time interval and output (Mishra and Singh 2003).

Mishra and Singh 2003 also explain that according to Woodward \& Gburek (1992), there are two main factors that hinder adaptation of some of the most successful models in developing countries such as India, Pakistan, Nepal, and other Asian and African countries. The first is that some models may require hydrological information which water managers do not yet have the capacity to gauge, while the second is that some models may contain too many parameters which vary across basins and are difficult to estimate. Model practicality, coupled with limited data availability, further translate into reliability issues in performance.

The SCS-CN model is relatively simple and can perform well with a basic level of hydrological data, explaining its popularity among water managers and practitioners in Indonesia as one of the models of choice for runoff estimation. In 2007, a paper by Geetha et al. (2007) proposed a modification to the established $\mathrm{CN}$ model. Tested in four river basins in India located in different climatological settings, the modified $\mathrm{CN}$ procedure showed better performance than the standard model. This paper proposes to evaluate the modification to the $\mathrm{CN}$ model in an Indonesian climate setting in order to assess the merit of replacing the standard model in future practice.

Numerous studies have emphasized the impacts of climate change, LULC changes and/or population growth on water availability (Kumar et al., 2018; Nikam et al., 2018). Other studies have addressed more specific changes, such as the affect of water resource availability on the growth in house prices (Wu et al., 2018). Moreover, Lakshmi et al. (2018) conducted research on how satellite remote sensing can be used over large areas and long time periods to identify spatial and temporal variations. They also studied how to estimate total water fluctuations using a simple water balance model, and how to compare hydrologic phenomena across hydrologic regions. One common conclusion from all these studies is that the amount of water available is decreasing as a result of both climate change and increasing population.

The development of GIS technology has further increased its popularity in the processing, management, analysis, and presentation of digital data. Current utilization of GIS includes the spatial processing of data for analysis and modelling of water resource systems. The integration of GIS in such modelling for decision-making purposes has been practiced since the beginning of the 21st century, when spatial database and capable GIS software was introduced (Wade et al., 2012; Zerger \& Ingle, 2003, cited in Osta \& Masoud, 2015b). Several recent studies of water resource management integrating the use of GIS are Behailu et al. (2014), Hanson et al. 
(2014), Herrera-Pantoja et al. (2015), Mora et al. (2014), Perrin et al. (2012), Post et al. (2012) and Gunawan et al. (2013).

This study aims to conduct a runoff analysis using the SCS-CN method integrated with GIS to estimate water availability. Studies on runoff estimation using such a combined approach have been previously conducted by, for instance, Bank (2010), Mahmoud (2014), Mishra et al. (2012), Osta and Masoud (2015), Singh and Goyal (2017), Uwizeyimana et al. (2019) and Zelelew (2017).

Considering this background, this study therefore intends to estimate water availability using the modified SCS-CN model. This model reasonably simulates catchment response and is applicable to watersheds of a complex nature (Geetha et al. 2007). The study focuses on upper Cisadane catchments located in west Java, Indonesia (Fig. 1). Water availability estimation from this catchment area is needed to understand changes in river flow and as information for PDAM Tirta Pakuan in meeting the clean water needs of Bogor city.

The article is organized as follows. In the first section, the methodology and data will be discussed, explaining which data and methods were used, and how water availability was estimated. The second section discusses the results of the SCS-CN model employed, which determines the Curve Number $(\mathrm{CN})$ variable using Antecedent Moisture Condition (AMC).

Finally, in the third part of the article, the performance of the calibrated and validated model is evaluated using stream flow data, and statistical evaluation is employed as the objective function to assess model performance. Model evaluation was conducted using 1) the correlation coefficient $\left(\mathrm{R}^{2}\right)$, and 2) Nash-Sutcliffe efficiency (NSE). According to Waseem et al. (2017), NSE and $R^{2}$ can give better agreement even for very poor models.

\section{METHODS}

The study was conducted in four steps. The first step was analysis of the hydrological and climatological data using hydrological rules, as described in subsections 2.2 and 2.4. The second step was analysis of the spatial variation of the catchment area using GIS, and is described in subsections 2.1, 2.2 and 2.3. The third step was runoff analysis as water availability estimation on the upper Cisadane catchment area using SCS-CN. The fourth and final stage was calibration and validation. The estimation of water availability and water demand is presented in the final subsection.

\subsection{Description of the Study Area}

The GIS analysis shows that geographically the upper Cisadane catchment area is located between longitudes $106^{\circ} 29^{\prime} 00^{\prime \prime}$ and $106^{\circ} 57^{\prime} 00^{\prime \prime}$ E and latitudes $06^{\circ} 30^{\prime} 20^{\prime \prime}$ and $06^{\circ} 46^{\prime} 30^{\prime \prime}$, an area of around $827.631 \mathrm{~km} 2$. The catchment outlet is located in Batubeulah at $106^{\circ} 41^{\prime} 21^{\prime \prime} \mathrm{E}$, $06^{\circ} 31^{\prime} 21^{\prime \prime}$ S, (Figure 1a).

The Cisadane river basin runs from Mount Salak, passing through Bogor to the Regency of Tangerang, before entering the Java Sea, a length of $137.8 \mathrm{Km}$. The climate of the Upper Cisadane is classified as wet tropical rainforest in the Koppen climate classification (Laksana 2011). 


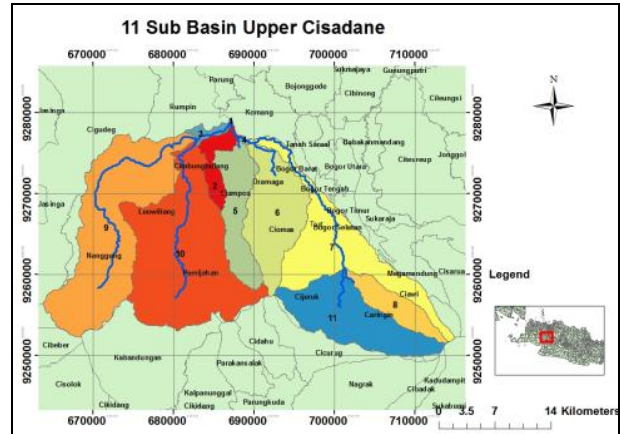

(a) Upper Cisadane sub-catchment area

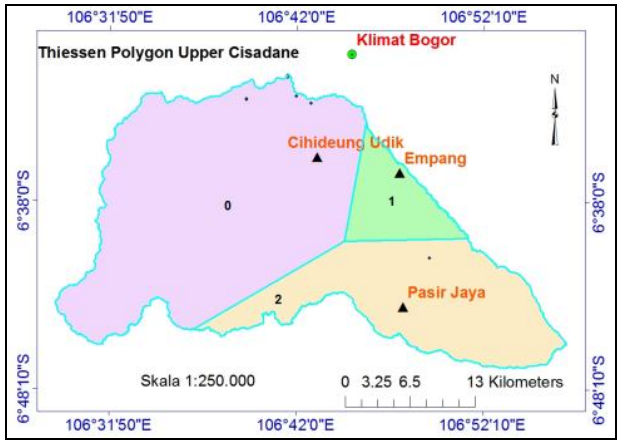

(b) Climatological stations

Figure 1 Location of the study area

\subsection{Climatology}

Figure 1a shows a digital map of the upper Cisadane catchment area. The Cisadane watershed consists of 11 sub-basins, with a total catchment area of $827.63 \mathrm{~km}^{2}$, and is located in a tropical area with high rainfall intensity. Figure $1 b$ is a digital map of the locations of the climatology stations used to obtain the research data. From the climatological data, it was observed that the monthly rainfall from year 2004 to 2009 ranged from 26 to $610 \mathrm{~mm}$, with a monthly average of around $300 \mathrm{~mm}$. Other data from the same period show maximum temperatures ranging from $28-34^{\circ} \mathrm{C}$, average humidity ranging from $76-89 \%$, solar radiation ranging from $15-48 \mathrm{n} / \mathrm{N}(\%)$, and wind speed from $2-54 \mathrm{~km} / \mathrm{hr}$.

\subsection{Land Use and Soil}

From the GIS analysis it was learnt that the watershed area is dominated by dry forest and bushes $(37 \%)$, rice fields $(21.5 \%)$ and secondary dry field forest $(15.6 \%)$. The area used for human settlement constitutes $7.6 \%$, with the remaining area $(17.93 \%)$ comprising vegetation forest, plantations, dry agricultural land, open fields, bodies of water and brush (Figure 2a).

According to Sulaeman et al. (2013), the watershed consists of moderate to very steep slopes, with elevations ranging from 71 to $2607 \mathrm{~m}$ above sea level. The main rock types found in the area are volcanic intermediary and sedimentary coarse felsic, exposed since the Holocene, Pleistocene and Middle Miocene periods. The predominant soils in the watershed are brown latosols (inceptisols), followed by reddish brown latosols (ultisols) and yellowish brown andisols (Figure 2b).

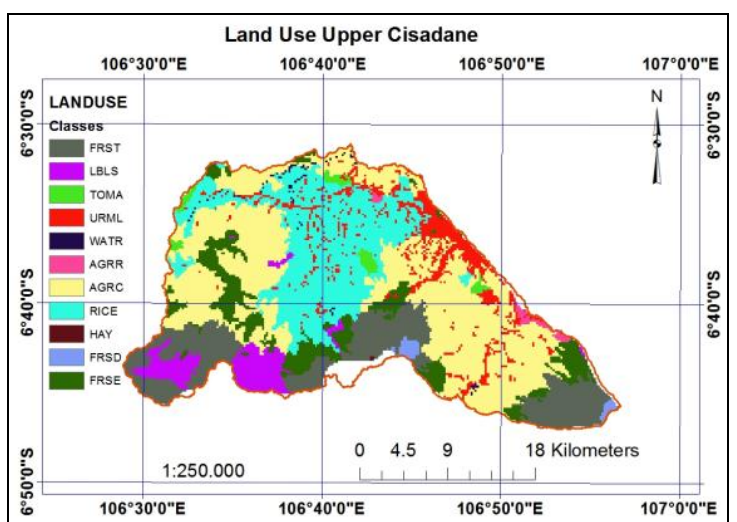

(a)

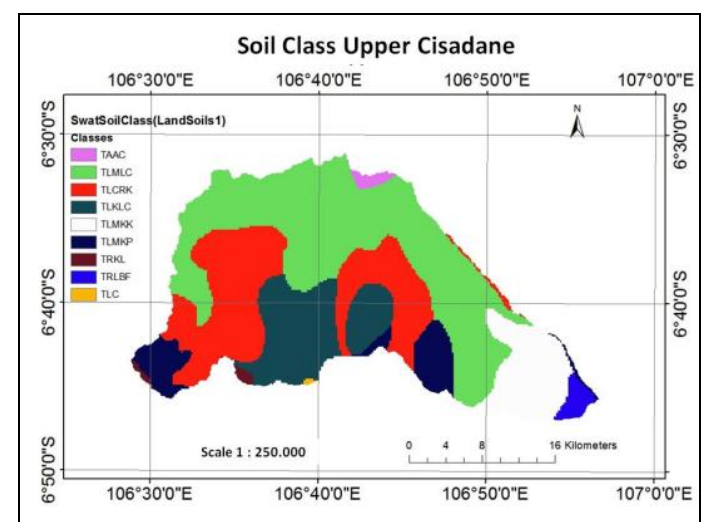

(b)

Figure 2 Upper Cisadane map of (a) Land use; (b) soil class

\subsection{Q Observation and Rainfall Data}

Rainfall data was obtained from observation stations around the areas representing the Upper Cisadane catchment. The rain measuring stations used were Pasir Jaya, Empang and Cihideung 
Udik. In addition, Q observation was obtained from the discharge measurement point at Batu Belah. The rainfall data are presented as water level ( $\mathrm{mm}$ units) and flow rates or discharge (m3/s units).

The Double Mass Curve method was used to test the consistency of the rainfall and observed discharge data. Based on the trends observed, rainfall and flow data were sufficient for use in the study. The double mass curve of the rainfall vs. observed discharge, shown in Figure 3, also displays good agreement in the distribution of the discharges within the year.

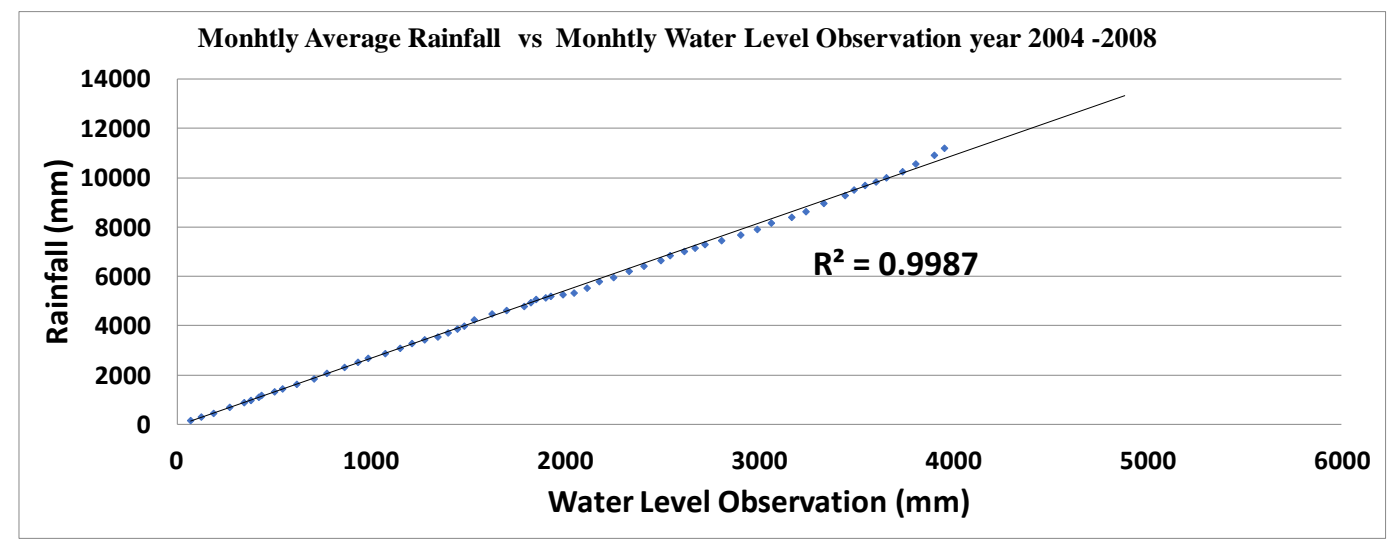

Figure 3 Hydrological data analysis

Rain pattern and water level or runoff graphs, from both 2004 and 2005, show fluctuating rainfall, yet relatively stable runoff (Figure 4); that is, the runoff trend generally follows the rain spread trend.

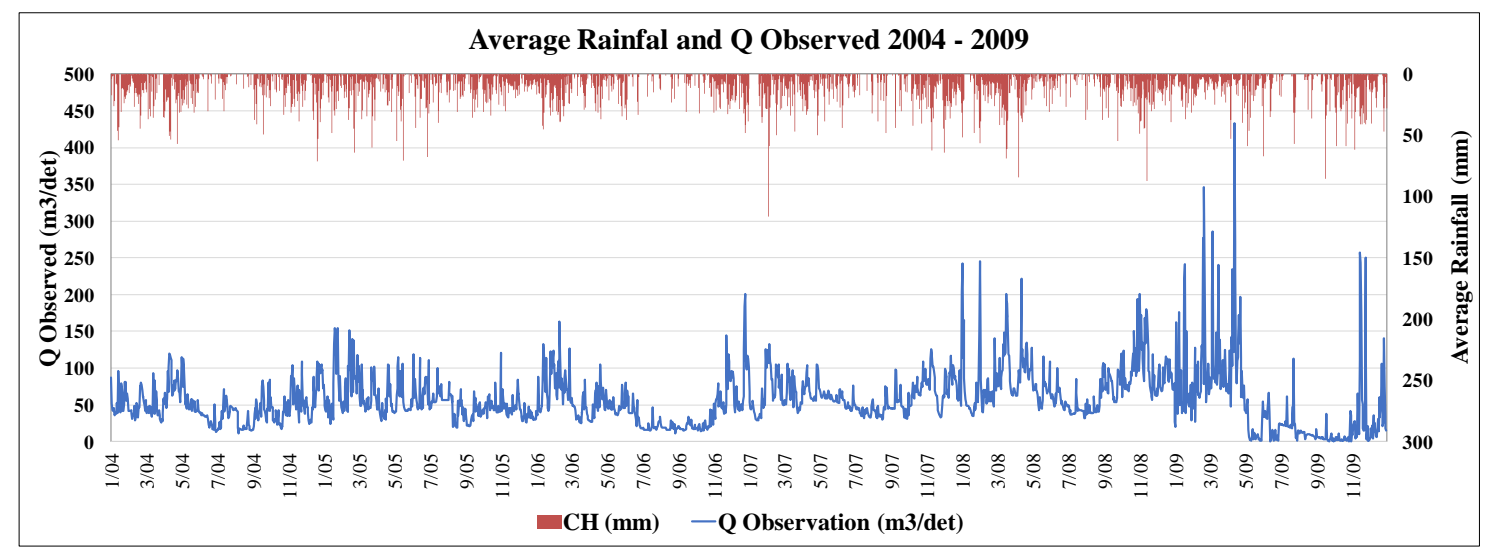

Figure 4 Daily average rainfall and Q (discharge) data observation

When rainfall increases sharply, runoff tends to increase, especially in events of continuous rain over successive months, e.g. January-August 2004. Peak rainfall occurs around two months after low rainfall. On the other hand, when rainfall decreases sharply, runoff tends to decrease in a more stable manner, e.g. in the periods February-July 2006 or March-July 2008. This suggests that runoff or river flow condition is in a good state. This data is also in accordance with the discharge pattern of research results (Julian et al. 2011).

\subsection{SCS-CN-based Long-term Hydrologic Simulation Model}

The SCS-CN method was used to calculate runoff (Geetha et al., 2007). SCS-CN-based longterm hydrologic simulation is a method of calculating daily direct surface runoff by using an AMC dependent $\mathrm{CN}$ (curve number). $\mathrm{CN}$ is calculated as a component that considers the types of soil and land use in the basin. Total runoff in this method is the sum of direct surface runoff and base-flow. Direct surface runoff is calculated at the river basin outlets. SCS-CN is an 
infiltration loss model, in which the part of the water that infiltrates is considered as the baseflow that runs into the river basin outlets. The hydrological components of this method are discussed in the following section.

\subsection{Calculation of Surface Runoff (RO)}

Surface runoff, RO, is calculated using the following procedures (Figure 5).

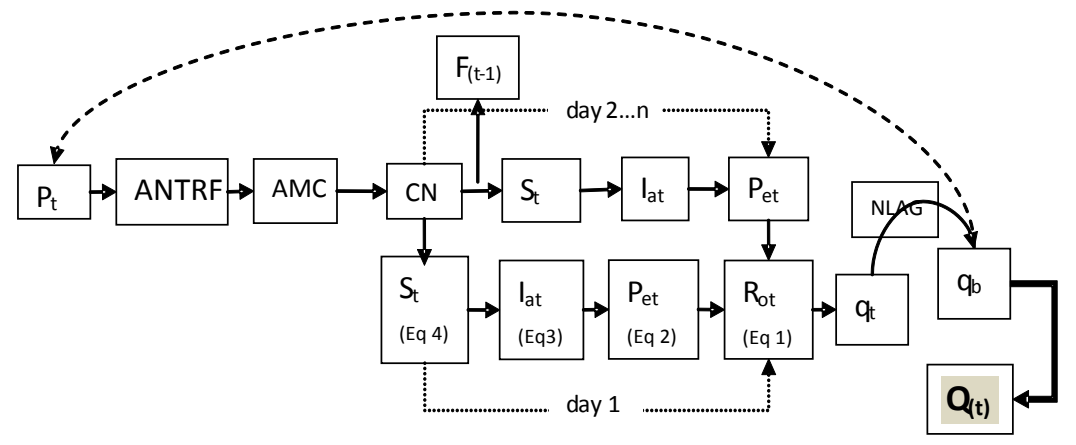

Figure 5 Runoff calculation procedures (Geetha et al., 2007)

where $\mathrm{P}$ is the total precipitation (mm), ANTRF is the amount of antecedent rainfall, AMC is the antecedent moisture condition, $\mathrm{CN}$ is coefficient that takes into account the soil conditions the $\mathrm{CN}$ value depends on the AMC level, with AMC depending on the last 5 days of rain (ANTRF), $\mathrm{F}$ is the cumulative infiltration $(\mathrm{mm}), \mathrm{S}$ is the potential maximum retention or infiltration $(\mathrm{mm}), S_{t}$ is the space available for water retention $(\mathrm{mm}), S_{\mathrm{t}-1}$ is the previous day's potential maximum retention $(\mathrm{mm}), \mathrm{I}_{\mathrm{a}}$ is the initial abstraction $(\mathrm{mm})$, NLAG is the lag parameter (days), and $\mathrm{Q}_{(\mathrm{t})}$ is the direct runoff $(\mathrm{mm})$.

The parameters, that is, the factors describing base flow $b f$, storage coefficient $K$, and the coefficient and exponent of the initial abstraction $\lambda 1$ and $\alpha$, parameters which were to be optimized, were calibrated. The performance of the calibration and validation model was evaluated using stream flow data.

\subsection{Dataset Size}

The hydrologic data collected for the study consisted of daily rainfall (2004-2009), evaporation and stream gauge records over a six years period (January 2004-December 2009) which were available for the upper Cisadane catchment area. Three years of water level observation data (2004-2006) were used for model calibration of upper Cisadane catchment, and two years of data (2008 and 2009) for validation. Spatial data was also used, namely, land use and soil map, DEM (Digital Elevation Map), and RBI (Rupa Bumi Indonesia) map.

\section{RESULTS AND DISCUSSION}

Model (Geetha et al., 2007) is based on the SCS-CN concept of simulating catchment response/behavior. The model is useful for deriving runoff from precipitation, with daily time steps needed to capture daily runoff variations.

\subsection{Simulation Runoff}

Figure 6 presents the monthly estimates of simulated runoff and the average rainfall. It shows that runoff rainfall, suggesting that the model works in accordance with the the water balance principle, in which runoff is lower than average rainfall. Note that the value of the runoff is usually stated in millimetres and therefore need to be adjusted to the units used to rainfall. 


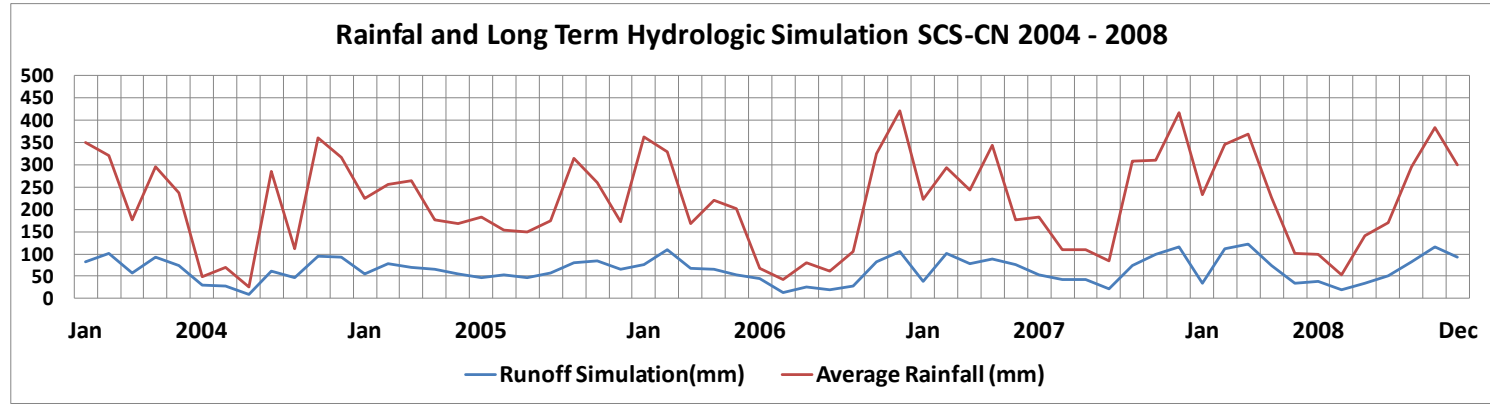

Figure 6 Runoff simulation and average rainfall

The model was calibrated to obtain one that best matches field realities. The simulation results were calibrated using flow data measured at Batu Beulah, and model output compared to the observed Q (Figure 7). The ranges/values of the parameters selected for the trials and optimization are given in Table 1.

Three years' of data (2004-2006) were used to calibrate the models for the upper Cisadane catchment, with two years' data (2007-2008) employed for validation.

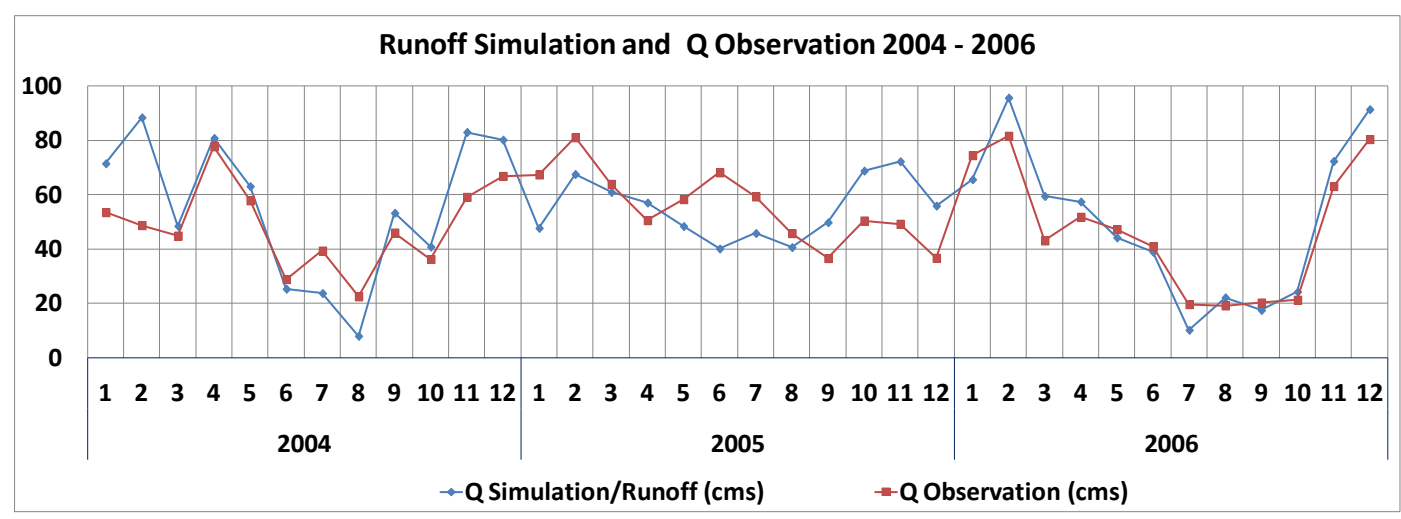

Figure 7 Runoff simulation for calibration

Table 1 Range of estimate parameters

\begin{tabular}{lccccc}
\hline Parameters & bf & $\mathrm{K}$ & $\lambda 1$ & $\alpha$ & NLAG \\
\hline Range & $0-2$ & $0-100$ & $0-10$ & $0-10$ & $0-10$ \\
Estimated & 0.82 & 20 & 0.2 & 10 & 10 \\
\hline
\end{tabular}

Tabel 2 Calibration and validation results

\begin{tabular}{cccc}
\hline Calibration & $\mathrm{R}^{2}$ & NSE & Relative error (\%) \\
\hline $2004-2006$ & 0.736 & 0.53 & 24.35 \\
\hline Validation & $\mathrm{R}^{2}$ & $\mathrm{NSE}$ & Relative error $(\%)$ \\
\hline 2007 & 0.85 & 0.43 & 37.5 \\
2008 & 0.68 & -0.368 & 16.58 \\
\hline
\end{tabular}

The parameters computed in the calibration of all the watersheds are given in Table 2. The calibrated monthly determination coefficient $\left(\mathrm{R}^{2}\right)$ and Nash-Sutcliffe efficiency value (NS) for 2004-2006 were 0.62 and 0.37 , respectively (Table 2 ).

The $\mathrm{R}^{2}$ and NSE values reveal that the model shows satisfactory performance in the upper Cisadane catchment area. Calibrating the model against $2004-2006$ data yielded values of $\mathrm{R}^{2}$ $=0.736$ and NSE $=0.53$ (Table 2). However, the model should give better performance, as we 
can see that the runoff simulation follow the trend of rainfall data quite perfectly. Comparing the runoff simulation and observation data, there are some deviation detected that might reduce the performance of the model, some difference in trend is noted in the period of early month of 2004 and April to July 2005 (Fig 7). Normalizing the observed Q value to the precipitation value for these period improved performance, yielding $\mathrm{R}^{2}=0.74$ and $\mathrm{NSE}=0.53$. It could be interpreted that the model should perform better than suggested with the $\mathrm{R}^{2}$ and NSE values calibrated against 2004 - 2006 data, assumed that Q behaves normally.

\subsection{Estimated Water Availability}

The model simulation results, shown in Table 3 and Figure 8, can be used to determine water availability in Bogor. They simulate runoff in the upper Cisadane catchment area of between $30-100 \mathrm{~m}^{3} / \mathrm{s}$ during the wet season (November-April) and between $28-65 \mathrm{~m}^{3} / \mathrm{s}$ during the dry season (May-October). Table 5 and Figure 10 show several sharp drops in August 2004, July 2006 and July 2008, which correspond to drops in precipitation at all three data points. This indicates the major role of precipitation in the model in simulating runoff.

Table 3 Water availability estimation $\left(\mathrm{m}^{3} / \mathrm{s}\right)$

\begin{tabular}{lccccr}
\hline \multicolumn{1}{c}{ Month } & 2004 & 2005 & 2006 & \multicolumn{1}{c}{2007} & \multicolumn{1}{c}{2008} \\
\hline January & 71.494 & 47.733 & 65.626 & 34.242 & 28.725 \\
February & 88.409 & 67.560 & 95.674 & 87.795 & 97.837 \\
March & 48.510 & 60.960 & 59.470 & 68.385 & 106.612 \\
April & 80.826 & 57.054 & 57.439 & 76.910 & 63.883 \\
May & 63.068 & 48.406 & 44.210 & 65.307 & 28.850 \\
June & 25.332 & 40.129 & 38.950 & 45.912 & 32.395 \\
July & 23.753 & 45.838 & 10.223 & 35.653 & 16.127 \\
August & 7.990 & 40.640 & 22.185 & 35.988 & 29.269 \\
September & 53.283 & 49.801 & 17.530 & 18.557 & 44.797 \\
October & 40.834 & 68.809 & 24.277 & 65.422 & 71.550 \\
November & 83.031 & 72.234 & 72.355 & 85.194 & 100.449 \\
December & 80.207 & 55.906 & 91.416 & 100.422 & 80.915 \\
\hline
\end{tabular}

This output could be presented to water managers as representing water availability at the observation point (Batu Belah).

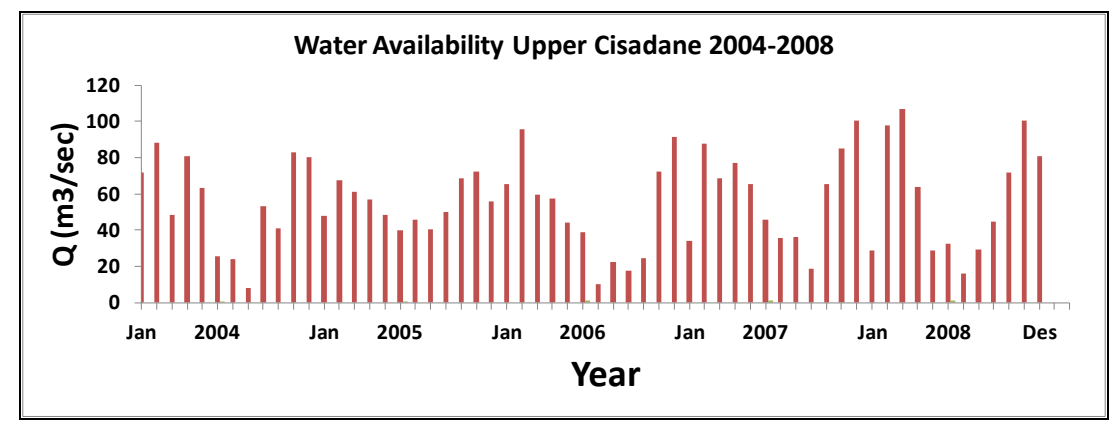

Figure 8 Water availability estimation

\subsection{Water Demand in Bogor City}

The increased need for clean water has been triggered by the flow of urbanization to the city of Bogor. The results of research conducted by Noperissa (2018) using the regression method showed that in 20 years' time domestic water demand will be $80,328,688.57 \mathrm{~m} 3 /$ year and total water demand 125,312,754.2 m3/year. Noperissa (2018) also stated that domestic water availability in Bogor would decrease, leading to a clean water shortage after 2049, when the population will have reached 1,720,323. According to Sabar and Mukmin (2006), the water 
demand of the Local Water Supply Enterprise of Bogor is at 1,225 L/sec in year 2005 . Factoring in the impact of population growth and city expansion, the need for raw water was calculated to increase to $2,375 \mathrm{~L} / \mathrm{sec}$ by 2010 . Hidayat and Yudistira (2018) calculated that domestic water demand based on the watershed boundary was 105,075 m3/day. Meanwhile, according to PDAM Tirta Pakuan data, average demand $(\mathrm{L} / \mathrm{sec})$ for raw water measured in yearly intervals from 2004 to 2009 were 777, 800, 840, 937, 1,051 and 1,166 L/sec respectively (Sabar and Mukmin 2006).

\section{CONCLUSION}

Using any model to simulate the long term hydrological behavior of a given watershed is not an easy task. Most, if not all, model input parameters vary significantly according to the season and hydrological/meteorological conditions. As indicated in the results and discussion section, the statistical tests on the developed model indicate that there is no evidence of a considerable difference between the simulated and the observed daily stream flows. Hence, it can be generally used with confidence to predict future behaviour of the watershed. However, it must be noted that the model is calibrated and validated on stream flow data from the period 2004 through 2008.

This model is very suitable for use as a tool in estimating water availability. Consequently, it can be concluded that the water availability in upper Cisadane can still meet the water demand for Bogor city from 2004 to 2008, but that there will be a shortage for the following 20 or 30 years. The SCS-CN method can be used to report water availability conditions, not only yearly, but also on a monthly or daily basis; however, modeling requires considerable time, effort and cost. The research will continue by employing other methods to better understand the shortcomings and advantages of the SCS-CN method.

\section{ACKNOWLEDGEMENT}

This research was funded by Ministry of Research and High Education Grand PDD 2018 with decree number 3/E/KPT/2018 and contract number 2108/LPPM/UP/III/2018.

\section{REFERENCES}

Burton, J.S.C., 1993. Proceedings of the Federal Interagency Workshop on Hydrologic Modeling Demands for the 90's. U.S. Geological Survey Water Resources Investigations Report 93-4018, Federal Center, Denver, Colorado

Dessu, S.B., Melesse, A.M., Bhat, M.G., Mcclain, M.E., 2014. Assessment of Water Resources Availability and Demand in the Mara River Basin. Catena, Volume 115, pp. 104-114

Geetha, K., Mishra, S.K., Eldho, T.I., Rastogi, A.K., Pandey, R.P., 2007. Modifications to SCSCN Method for Long-term Hydrologic Simulation. Journal of Irrigation and Drainage Engineering, Volume 133(5), pp. 475-486

Gunawan, G., Sutjiningsih, D., Soeryantono, H., Sulistioweni, W., 2013. Soil Erosion Estimation based on GIS and Remote Sensing for Supporting Integrated Water Resources Conservation Management. International Journal of Technology, Volume 4(2), pp. 147156

Hanson, R.T., Lockwood, B., Schmid, W., 2014. Analysis of Projected Water Availability with Current Basin Management Plan, Pajaro Valley, California. Journal of Hydrology, Volume 519(Part A), pp. 131-147

Herrera-Pantoja, M., Hiscock, K.M., 2015. Projected Impacts of Climate Change on Water Availability Indicators in a Semi-arid Region of Central Mexico. Environmental Science and Policy, Volume 54, pp. 81-89 
Hidayat, D.P.A., Yudistira, Y., 2018. Modelling of Domestic Water Demand using Spatial Data Population for Cisadane Upstream Watershed. Construction Engineering and Sustainable Development, Volume 1(1), pp. 16-22

IACWD, 1998. Proceedings of the First Federal Interagency Hydrologic Modeling Conference, Interagency Advisory Committee on Water (IACW), U.S. Geological Survey Reston, Virginia

Julian, M.M., Fumihiko, N., Poerbandono, Ward, P.J., 2011. Simulation of River Discharge in Major Watershed of Northwestern Java From 1901 to 2006. International Journal of Technology, Volume 2(1), pp. 37-46

Kumar, N., Singh, S.K., Singh, V.G., Dzwairo, B., 2018. Investigation of Impacts of Land Use/Land Cover Change on Water Availability of Tons River Basin, Madhya Pradesh, India. Modeling Earth Systems and Environment, Volume 4(1), pp. 295-310

Laksana, I., 2011. Kalibrasi dan Validasi Model Mw SWAT pada Analisis Debit Aliran Sungai Sub Das Cisadane Hulu (Calibration and Validation of the Mw SWAT Model in the Cisadane Hulu River Basin Watershed Analysis). Undergraduate thesis, Bogor Agricultural Institute (IPB)

Lakshmi, V., Fayne, J., Bolten, J., 2018. A Comparative Study of Available Water in the Major River Basins of the World. Journal of Hydrology, Volume 567, pp. 510-532

Mahmoud, S.H., 2014. Investigation of Rainfall-Runoff Modeling for Egypt by using Remote Sensing and GIS Integration. Catena, Volume 120, pp. 111-121

Mishra, S.K., Pandey, A., Singh., V.P., 2012. Special Issue on Soil Conservation Service Curve Number (SCS-CN) Methodology. Journal of Hydrologic Engineering, Volume 17(11), pp. 1157

Mishra, S.K., Singh, V.P., 2003. Soil Conservation Service Curve Number (SCS-CN) Methodology. Water Science and Technology Library, Springer Science+Business Media B.V., Springer, Dordrecht

Nikam, B.R., Garg, V., Jeyaprakash, K., Gupta, P.K., Srivastav, S.K., Thakur, P.K., Aggarwal, S.P., 2018. Analyzing Future Water Availability and Hydrological Extremes in the Krishna Basin under Changing Climatic Conditions. Arabian Journal of Geosciences. Volume 11(581), pp. 1-16

Noperissa, V., Waspado, R.S.B., 2018. Analisis Kebutuhan dan Ketersediaan Air Domestik Menggunakan Metode Regresi di Kota Bogor (Analysis of Domestic Water Needs and Availability using Regression Methods in the City of Bogor). Civil and Enviromental Engineering Journal, Volume 3(3), pp. 127-138

Osta, M.M.E., Masoud, M.H., 2015. Implementation of a Hydrologic Model and GIS for Estimating Wadi Runoff in Dernah Area, Al Jabal Al Akhadar, NE Libya. Journal of African Earth Science, Volume 107, pp. 36-56

Perrin, J., Ferrant, S., Massuel, S., Dewandel, B., Maréchal, J.C., Aulong, S., Ahmed, S., 2012. Assessing Water Availability in a Semi-arid Watershed of Southern India using a Semidistributed Model. Journal of Hydrology, Volume 460-461, pp. 143-155

Post, D.A., Chiew, F.H.S., Teng, J., Viney, N.R., Ling, F.L.N., Harrington, G., Crosbie, R.S., Graham, B., Marvanek, S., Mcloughlin, R., 2012. A Robust Methodology for Conducting Large-scale Assessments of Current and Future Water Availability and Use: A Case Study in Tasmania, Australia. Journal of Hydrology, Volume 412-413, pp. 233-245

Sabar, A., Mukmin, Y., 2006. Cisadane River Water Reliability Study Meets Bogor City PDAM Raw Water Demand Rate. Urban and Regional Planning, Volume 17(2), pp. 5874

Schwank, J., Escobar, R., Girón, G.H., Morán-Tajeda, E., 2014. Modeling of the Mendoza River Watershed as a Tool to Study Climate Change Impacts on Water Availability. Environmental Science \& Policy, Volume 43, pp. 91-97 
Shadeed, S., Almasri, M., 2010. Application of GIS-based SCS-CN Method. Water Science and Engineering, Volume 3(1), pp. 1-13

Singh, V., Goyal, M.K., 2017. Curve Number Modifications and Parameterization Sensitivity Analysis for Reducing Model Uncertainty in Simulated and Projected Stream Flows in a Himalayan Catchment. Ecological Engineering, Volume 108(Part A), pp. 17-29

Sulaeman, Y., Mulyani, A., Wahyunto, Sarwani, M., 2013. Mapping Soil Depth Characteristics using Digital Soil Mapping Techniques to Monitor Land Degradation. In: P. Limtong, W. Sirichuaychoo, T. Chitchumnong, C. Dissatapon, W. Waramit, C. Leaungvutiviroj, A. Jaichuen (Eds.), Sustainable Land Management to Enhance Food Production of APEC Members. Proceeding of Workshop, Chiang Mai, November 28-30, pp. 1-195

Uwizeyimana, D., Mureithi, S.M., Mvuyekure, S.M., Karuku, G., Kironchi, G., 2019. Modelling Surface Runoff using the Soil Conservation Service-curve Number Method in a Drought Prone Agro-ecological Zone in Rwanda. International Soil and Water Conservation Research, Volume 7(1), pp. 9-17

Wade, A.J., Smith, S.J., Black, E.C.L., Brayshaw, D.J., Holmes, P.A.C., El-bastawesy, M., Rambeau, C.M.C., Mithen, S. J., 2012. A New Method for the Determination of Holocene Palaeohydrology. Journal of Hydrology, Volume 420-421, pp. 1-16.

Waseem, M., Mani, N., Andiego, G., Usman, M., 2017. A Review of Criteria of Fit for Hydrological Models. International Research Journal of Engineering and Technology (IRJET), Volume 4(11), pp. 1765-1772

Woodward, D.E., Gburek, W., 1992. Progress report ARS/SCS Runoff Curve Number Work Group. In: Proceeding D.E. Woodward, USDA-SCS, Washington DC, United States, pp. 378-382

Wu, T., Yu, Y., Wang, B., 2018. Water Resources Availability and the Growth of Housing Prices in China. Resources, Conservation \& Recycling, Volume 128, pp. 555-562

Wurbs, R.A., 1998. Dissemination of 'Generalized Water Resources Models in the United States,' Water International, Volume 23, pp. 190-198

Zelelew., D.G., 2017. Spatial Mapping and Testing the Applicability of the Curve Number Method for Ungauged Catchments in Northern Ethiopia. International Soil and Water Conservation Research, Volume 5(4), pp. 293-301

Zerger, A., Ingle, D., 2003. Impediments to using GIS for Real-time Disaster Decision Support. Computers, Environment and Urban Systems, Volume 27(2), pp. 123-141 